Croatian Journal of Education

Vol.21; No.2/2019, pages: 511-537

Original research paper

Paper submitted: $9^{\text {th }}$ February 2018

Paper accepted: $6^{\text {th }}$ March 2018

https://doi.org/10.15516/cje.v21i2.3088

\title{
Comparative Study of Motor Performances of the Boys with Different Body Mass Indices
}

Goran Šekeljić', Milovan Stamatović', Dragan Martinović and Vladan Pelemiš²

${ }^{1}$ Faculty of Education, University of Kragujevac

${ }^{2}$ Faculty of Teacher Education, University of Belgrade

\section{Abstract}

The goal of this study is to compare motor abilities of the boys with different body mass indices and determine whether the children are obese or overweight, and to what extent their motor skills are inadequate in comparison to normally nourished children. The sample consisted of 180 grade four students, aged 10 ( \pm 6 months), from five primary schools in Užice (The Republic of Serbia). On the basis of the $B M I$ results, the sample was divided into four subsamples: malnourished $(N=30)$, normally nourished $(N=90)$, pre-obese $(N=30)$ and obese $(N=30)$. The evaluation of nine motor abilities was conducted by the battery of eighteen tests. The examinees from the group of the malnourished children (AW) achieved the lowest score in 7 out of 18 tests. The group of normally nourished children (NW) did not achieve the worst average score in any of the tests, and in 10 out of 18 tests they achieved the best average score. The group of pre-obese ones $(O W)$ achieved the best average score in 8 out of 18 tests, and the group of obese participants $(O B)$ achieved the lowest average scores on 11 out of 18 tests, and they did not achieve the best average scores in any of the tests. The research results indicate that the groups of pre-obese and obese persons have certain problems in motor dimension in the segment which is related to the showing of muscle strength and power, in the segment of showing speed and in the segment of balance.

Key words: body mass index; differences; motor abilities; obesity.

\section{Introduction}

The tendency of increasing frequency of excessive body weight and obesity in children is a current problem in most of the countries in the world. For children and adolescents, obesity is defined as an increase of the body mass above the reference 
values which were determined for the gender, age and body height, and the result is the increased amount of fat in the organism (Pelemiš, Macura, \& Branković, 2017). There are several forms of obesity: "ordinary", constitutional, hypothalamus and syndrome obesity (Peterkova \& Kosigina, 2011). The quantity of the fat tissue can be evaluated in several ways: by measuring the thickness of subcutaneous folds, by body mass index (BMI), by bioelectric impedance, and by water dilution method, although some subjective methods are also known, such as silhouette method. In everyday practice, the level of obesity is most frequently evaluated on the basis of the body mass index - BMI, which represents the quotient of body mass $(\mathrm{kg})$ and the square of body height $(\mathrm{m})$. BMI is used as a screening tool to identify possible weight problems for children (Pelemiš et al., 2016). This way shows satisfactory level of correlation of the direct measurement of the content of body fat of adults, as well as children (Rosner, Prineas, Loggie, \& Daniels, 1998), with the thickness of skin fold on triceps and the thickness of the waist (Jovanović, Nikolovski, Radulović, \& Novak, 2010). The research (Aycan, 2009) has shown that worldwide, in the first decade of the $21^{\text {st }}$ century, the annual prevalence of obesity rose by $6 \%$ in almost all age groups. The problems with overweight appear at an early age, and it is considered that today more than $10 \%$ of the world population of school children are overweight (Martinović \& Pelemiš, 2015). According to the data of The World Health Organization (WHO, 2000), in the USA in 2000 there were $20 \%$ obese adults, and it was estimated that in 2015 there would be $30 \%$, while in 2025 there would be more than $40 \%$ obese adults. According to the data of the International working group for obesity for 2005, Serbia is almost at the top of the list of countries with the increase in the prevalence of obesity in children (Wang \& Lobstein, 2006). The problem of obesity is more evident in adults (Živić, Ćirić, \& Stanković, 2011), because in 2000, more than a half of the total population of Serbia had problems with body weight. More precisely, $54 \%$ of adults were overweight, out of which $36.7 \%$ fall into the category of pre-obese people, and $17.3 \%$ into the category of the obese ones. The prevalence of obesity in children in Serbia is estimated at $19 \%$.

Apart from the fact that obesity increases health risks and that it influences further diminishing of physical activity, the results of the study (Sarkar, Singh, Bansal, \& Kapoor, 2011) indicate that overweight contributes to motor inadequacy, weaker motor abilities and motor skills, which generally can have negative effects on the overall motor development. Children with low level of motor abilities participated less in physical activities and they took part in sport or organized games on a smaller scale. Unlike them, people whose motor skills were better developed in the childhood period are expected to be more active as adolescents (Mandić, Martinović, \& Pelemiš, 2017; Morano, Colella, \& Caroli, 2011).

Motor abilities enable all human activities. Inadequacy in motor skills dimension for any reason leads to reduced motor engagement of children, which contributes to smaller level of activity, weaker motor skills and accumulation of fat. It creates health problems, problems in self-concept and various problems in socialization. Obesity 
influences reduction of physical activity during Physical Education lessons as well as during physical activity in free time (Prskalo, 2015). Preschools and schools, in cooperation with health institutions, should identify physical activities adapted to obese persons, to motivate their participation in sports in order to reduce differences in the basic motor abilities and to develop interest in social interactions. The prevention of inadequacy in motor skills dimension is important because in that way all children get the same chance for successful development (Prskalo, Horvat, \& Hraski, 2014). This study should provide the answer to the question which categories of nutritional status of children contribute to a better performance of motor skills, since there is no evidence that research of this kind has been carried out on the territory of The Republic of Serbia. Such findings would enable better planning of the teaching content in Physical Education as a school subject.

This research was realized with the goal to compare motor abilities of the boys who are, according to the recognized standards, classified into the categories of malnourished, normally nourished, pre-obese and obese persons. Because of that it can be said that the goal of this study was to compare the motor abilities of the boys with different body mass indices and determine if obese children or the overweight ones, and to what extent, exhibit motor inadequacy in comparison to normally nourished children.

\section{Methods}

The research sample consisted of 180 fourth-grade students aged 10 ( \pm 6 months) from five primary schools in Užice (The Republic of Serbia). On the basis of the results of the participants' BMI values, the sample of respondents was divided into four subsamples: malnourished (30), normally nourished (90), pre-obese (30) and obese children (30). BMI represents the quotient of the body mass $(\mathrm{kg})$ and the square of body height (m). According to the data of the WHO (2000), the participants whose BMI was under 18.5 were classified into the group of malnourished children; those whose BMI was between 18.5 and 24.9 were classified as normally nourished, those with BMI between 25 and 29.9 were classified as pre-obese and examinees whose BMI was over 30 were classified as the obese ones.

The evaluation of the nine motor abilities was performed by the battery of 18 tests which had been used by Kurelić, Momirović, Stojanović, Radojević, and Viskić-Štalec (1975). The explosive strength was evaluated by two tests - Standing long jump $(\mathrm{cm})$ and Throwing a medicine ball $(\mathrm{cm})$, repetitive strength was evaluated by the tests Lifting the trunk for 30 seconds (freq) and Stretching of the trunk (freq), while statistical force was evaluated by the tests Hanging pull-ups ( $\mathrm{sec}$ ) and Dynamometry of a hand (kp). The sprinter's speed was evaluated by two tests: 20 -meter running with a flying start (sec) and 30-meter running from the spot (sec), segmentary speed was evaluated by Hand plate tapping (freq), and Leg plate tapping (freq). Flexibility was evaluated by the Deep bent on the bench $(\mathrm{cm})$ and Spagat $(\mathrm{cm})$ tests, balance 
was evaluated by Standing on one leg with closed eyes (sec), and Standing on one leg across the balance bench (sec). Coordination was evaluated by the Twenty steps with moving through the sticks (sec), and Throwing the ball against the wall in 15 seconds (freq) tests, and for the precision Shooting the horizontal target with a small ball (freq), and Shooting the vertical target - darts (freq) tests were used.

The significance of differences between formed subsamples was tested by multivariate analysis of variance (MANOVA). For variables where statistically significant $F$ value was achieved, the "LSD" post hoc test was used in further analysis to determine the differences between the mean values of groups. Statistical significance was tested at a significance level of $\mathrm{p}<0.05$. All the data were analyzed by the application of IBM SPSS (version 19.0) statistical software package for Windows.

\section{Results}

The results (MANOVA) $(\mathrm{F}=2.010 ; \mathrm{p}=.000)$ indicate that in the multivariate space of the variables for the evaluation of motor abilities between the groups there are statistically significant differences. The results of the one-way analysis of variance (ANOVA) (Table 1) indicate that there is a statistically significant difference between the groups in 7 variables (long jump: $\mathrm{f}=10.360, \mathrm{p}=.000$; lifting the trunk: $\mathrm{f}=2.830$, $\mathrm{p}=.041$; stretching the trunk: $\mathrm{f}=2.545, \mathrm{p}=.042$; hanging pull-ups: $\mathrm{f}=8.977, \mathrm{p}=.000 ; 20 \mathrm{~m}$ running: $\mathrm{f}=9.652, \mathrm{p}=.000 ; 30 \mathrm{~m}$ running: $\mathrm{f}=6.530, \mathrm{p}=.000$; standing on one leg across the balance bench: $\mathrm{f}=2.432, \mathrm{p}=.050$ ).

By analyzing statistical parameters (Table 1) it can be seen that the examinees from the group of malnourished children (AW) achieved the lowest score in 7 out of 18 tests: Throwing a medicine ball, Lifting the trunk, Dynamometry of a hand, Hand plate tapping Spagat, Standing on one leg with closed eyes and Bouncing of a ball. These examinees did not achieve the best average score in any of the tests as a group. It was only in the tests Lifting the trunk and Standing on one leg across the balance bench that they achieved the scores which were statistically worse, and only in comparison with the group of normally nourished children.

The group of the examinees classified as normally nourished (NW) did not achieve the lowest average score in any of the tests. This group achieved the best average score in 10 out of 18 tests (Long jump, Lifting the trunk, Stretching the trunk, Hanging pullups, $20 \mathrm{~m}$ running, 30m running, Hand plate tapping, Deep bent, Standing on one leg with closed eyes and Darts).

The examinees from the group of pre-obese children (OW) did not achieve the lowest average score in any of the tests, while in 8 out of 18 tests (Throwing the medicine ball, Dynamometry of a hand, Leg plate Tapping, Spagat, Standing on one leg across the balance bench, Throwing the ball and Shooting the horizontal target) they achieved the best average score. In the tests Lifting the trunk, and Standing on one leg across the balance bench they achieved the scores which were statistically significantly worse than the scores of the group of normally nourished children. 
The group of obese examinees (OB) achieved the lowest scores in 11 out of 18 tests (Long jump, Deep bent, Hanging pull-ups, 20m running, 30m running, Leg plate Tapping Standing on one leg across the balance bench, Pulling a stick Shooting the horizontal target and Darts). This group did not achieve the best average score in any of the tests in comparison to other groups of examinees. Statistically, they were worse in tests: Long jump, Stretching of the trunk, Lifting the trunk, $20 \mathrm{~m}$ running, $30 \mathrm{~m}$ running, Standing on one leg across the balance bench.

\section{Table 1}

The differences in motor abilities of the boys who were classified into four groups according to the BMI (ITM): malnourished (AW), normally nourished (NW), pre-obese (OW) and obese(OB)

\begin{tabular}{|c|c|c|c|c|c|c|c|c|c|c|}
\hline \multirow{2}{*}{ Variables } & \multicolumn{2}{|c|}{ AW $(n=30)$} & \multicolumn{2}{|c|}{ NW $(n=90)$} & \multicolumn{2}{|c|}{ OW $(n=30)$} & \multicolumn{2}{|c|}{$O B(n=30)$} & & \multirow{2}{*}{ p } \\
\hline & $M$ & SD & M & SD & $M$ & SD & M & SD & & \\
\hline Long jump (cm.) & 141.50 & 11.79 & 148.06 & 16.91 & $137.03^{b}$ & 22.11 & $117.5^{\mathrm{abc}}$ & 10.60 & 10.36 & .000 \\
\hline Throwing a medicine ball $(\mathrm{cm})$. & 341.00 & 44.83 & 373.67 & 71.88 & 403.33 & 73.58 & 346.00 & 100.68 & 2.60 & .055 \\
\hline Lifting the trunk (freq.) & $13.50^{\mathrm{b}}$ & 4.62 & 16.93 & 3.68 & 16.22 & 5.18 & $14.30^{b}$ & 4.85 & 2.83 & .041 \\
\hline Stretching the trunk (freq.) & 13.40 & 8.85 & 15.10 & 8.29 & $12.40^{\mathrm{b}}$ & 8.08 & $7.20^{\mathrm{abc}}$ & 4.69 & 2.54 & .042 \\
\hline Hang up bent (sec.) & 18.36 & 16.69 & 24.06 & 17.13 & $11.14^{\mathrm{ab}}$ & 10.89 & $2.86^{\mathrm{abc}}$ & 2.23 & 8.97 & .000 \\
\hline Dynamometry of a hand (kp.) & 61.14 & 7.41 & 71.63 & 12.83 & 72.16 & 13.29 & 70.43 & 12.04 & 2.19 & .092 \\
\hline $20 \mathrm{~m}$ running (sec.) & 3.85 & .46 & 3.75 & .32 & 3.98 & .38 & $4.35^{\mathrm{abc}}$ & .31 & 9.65 & .000 \\
\hline $30 \mathrm{~m}$ running (sec.) & 6.26 & .64 & 6.13 & .45 & 6.36 & .40 & $6.81^{\mathrm{abc}}$ & .40 & 6.53 & .000 \\
\hline Hand plate tapping (freq.) & 26.50 & 4.83 & 29.96 & 3.97 & 29.44 & 4.70 & 29.60 & 6.02 & 1.85 & .142 \\
\hline Leg plate Tapping (freq.) & 18.50 & 2.50 & 18.73 & 2.40 & 19.00 & 3.01 & 17.00 & 2.30 & 2.31 & .079 \\
\hline Deep bent $(\mathrm{cm})$. & 15.20 & 7.00 & 18.54 & 6.77 & 17.51 & 6.27 & 13.70 & 6.71 & 2.08 & .106 \\
\hline Spagat (cm.) & 131.50 & 6.68 & 135.25 & 10.43 & 135.55 & 12.19 & 132.00 & 10.59 & .64 & .587 \\
\hline $\begin{array}{l}\text { Standing on one leg across the } \\
\text { balance bench (sec.) }\end{array}$ & $4.64^{b}$ & 2.81 & 7.25 & 3.35 & 6.38 & 3.21 & $2.74^{\mathrm{bc}}$ & 1.02 & 2.43 & .050 \\
\hline $\begin{array}{l}\text { Standing on one leg with closed } \\
\text { eyes (sec.) }\end{array}$ & 18.76 & 7.91 & 21.38 & 13.02 & 21.07 & 16.43 & 21.37 & 13.10 & .04 & .989 \\
\hline $\begin{array}{l}\text { Twenty steps with moving } \\
\text { through the sticks (sec.) }\end{array}$ & 40.06 & 13.71 & 37.56 & 10.05 & 41.07 & 22.40 & 37.05 & 5.88 & .51 & .670 \\
\hline Bouncing of a ball (freq.) & 15.30 & 3.02 & 15.92 & 3.26 & 17.03 & 2.79 & 15.70 & 3.52 & 1.12 & .340 \\
\hline $\begin{array}{l}\text { Shooting a horizontal target } \\
\text { (freq.) }\end{array}$ & 8.10 & 5.21 & 9.96 & 5.25 & 10.07 & 4.81 & 8.09 & 5.38 & .75 & .523 \\
\hline Darts (freq.) & 4.30 & 4.01 & 5.18 & 4.51 & 4.11 & 3.92 & 2.80 & 2.25 & .92 & .432 \\
\hline
\end{tabular}

$$
\mathrm{F}=2.010 ; P=.000
$$

Legend: AW - malnourished; NW - normally nourished; OW - pre-obese; $O B$ - obese; $M$ - arithmetic mean; SD standard deviation; $F$ - multivariate Wilks' $F$ test; $P$ - statistical significance of multivariate $F$ test; $f$-test for one-way analysis of variance; $p$ - the level of statistical significance between the groups for one variable. ${ }^{a}=$ significantly different with underweight, ${ }^{b}=$ significantly different with normal, ${ }^{c}=$ significantly different with overweight, ${ }^{d}$ $=$ significantly different with obese.

\section{Discussion}

The results in this study indicate that there is a significantly smaller level of motor abilities in obese children. This is in accordance with the studies (Đokić \& Međedović, 2013; Gentier, D’Hondt, Shultz, Deforche, Augustijn, Hoorne, \& Lenoir, 2013), which 
indicate lagging in the development of motor abilities of obese persons. Investigations of children's habits confirmed that inactive way of life leads to motor deficiency and overweight and obesity. Normally nourished children perform more daily activities, and according to the authors it is the main cause for bigger advancement in motor dimension since children's motor abilities are not developed solely through maturation processes, but they are also taught and enhanced by exercising (Logan, ScrabisFletcher, Modlesky, \& Getchell, 2012).

\section{The Relationship between BMI and Test Scores for the Evaluation of Speed, Agility and Explosive Strength}

According to the studies (Yusof, Aiman, Zawi, Hasan, \& Radzi, 2013), the reasons for motor inadequacy of obese persons must have been anatomical and physiological in nature since these are the factors which determine motor abilities. The authors are led by the following analogy. If anatomical and physiological factors are crucial, then there must be differences in morphology and the structure of the tissues and organs because the differences in motor dimension can be realized only by the application of the factors which determine it. This statement was confirmed by many studies. For example, frequent valgus 20 degrees in lower extremities in pre-obese and obese persons is a consequence of high MDA angles, the angles between methaphisal horns and lines drawn on tibial axis (Wearing, Hennig, Byrne, Steele, \& Hills, 2006). The skeletal structure of lower extremities is changing because of obesity, and the changes appear on ankles, feet and toes, which grow bigger, become wider, taller and fatter (Sarkar et al., 2011). Apart from the fact that they are thicker, they do not possess enough mineral density which would successfully endure heavier burden, therefore the prevalence of musculoskeletal pain in the area of back, hips, legs, knees, ankles and feet is significantly higher in obese adolescents (Taylor, Theim, Mirch, Ghorbani, Tanofsky-Kraff, Adler-Wailes, \& Yanovski, 2006).

This finding was also confirmed in our study because obese people, statistically, achieved low scores in tests Standing long jump, 20-meter running, and 30-meter running. These are the tests for the evaluation of explosive strength of lower extremities and the speed of movement, and to a significant extent they depend on anatomical and physiological state of locomotor apparatus and the system which controls postural stability (vestibular apparatus and nerve structures which are connected with different kinesthetic receptors in muscles, bones and joints). In the test used to evaluate the segmentary speed of the extremities Hand plate tapping and Leg plate Tapping in this and another study (Sporiš, Badrić, \& Miljković, 2014), the differences were not stated between the groups, because during testing the examinees move small body parts so that the changes in posture do not significantly influence the test scores.

\section{The Relationship between BMI and Test Score for Balance Evaluation}

The problems in postural status can be the key to understanding the problem obese people have in keeping the balance. The movement of the body forward increases 
the prong of the force and by this creates bigger rotation moment of the force in the centers of rotation in the joints of lower extremities. Because of that the muscles that compensate the movement of the body forward are more engaged with the goal of keeping the balance (Dowling, Steel, \& Baur, 2004). A long-term engagement of the muscles leads to their faster tiring, which hardens the keeping of body balance, by which the lower scores of obese people on the balance tests are explained. Besides, instability enhances the inert characteristic which the body performs because of the overweight, which significantly hardens the functioning of locomotor system which coordinates its functioning with vestibular apparatus and kinesthetic receptors (D'Hondt, Deforche, De Bourdeaudhuij, \& Lenoir, 2008). By the reduced influx of sensory information, the reduced balance of obese people is explained, and the authors believe that the loss of excess weight is the only solution for the improvement of the balance control. Similar studies were done by other authors, and the results and conclusions are similar. For example, in the study conducted by Li and Aruin (2007) the burden was added to the examinees amounting from $10 \%$ to $40 \%$ of their body weight in order to determine whether there would be changes in the projections of the leaning spot and how much it will influence the activity of postural muscles. There were changes in the projection of the leaning center, and electromyography recorded bigger contractility of the trunk muscles and the lower extremities muscles. The bigger the load, the bigger the contractions were. The results indicate that the changes in the body mass destabilize the body, which makes it necessary for CNS (central nervous system) to make compensation by additional engagement of postural muscles with the goal of body stabilization.

The study has shown how much of the muscle force is needed in order to react to keeping the body balance (Corbeil, Simoneau, Rancourt, Tremblay, \& Teasdale, 2001). Their calculations showed that obese people produce big rotation moment in ankles, even by small locomotion. Depending on the moment of the force by which the body weight and the gravitation act on the rotation centre, it is possible to calculate the quantity of the load suffered by ankles. The results show that sometimes, in order to keep the balanced position even in performing small activities, it is necessary to generate such muscle force that tested people do not possess, which causes the loss of balance and a fall.

The damaged sensory motor and neuromuscular function, as well as inadequate muscle force, make changes in the mechanics of the movement of obese people. The characteristic pattern of movement is an accented upright (stiff) posture with reduced bending in knees and hips. Besides, it is characterized by slow walking speed, slower rhythm and frequency of the steps, reduced length of the steps and by $13 \%$ to $42 \%$ bigger width of the steps. They have longer pauses and stressed periods of support on both feet and they make unnecessary oscillations in cranial part of the body. The angle that is closed by longitudinal lines between the feet (the line which connects the middle of the heel and the second toe) is bigger in obese people (Close, Lord, Menz, \& Sherrington, 2005). 
The studies conducted on the sample of normally nourished people of different age show small correlations between the strength of different muscle groups and postural stability (Muehlbauer, Gollhofer, \& Granacher, 2012), which means that these two motor characteristics are independent. In our study, the groups of obese people and the malnourished ones performed statistically significantly worse in the test Standing on one leg across the balance bench than the group of the normally nourished ones. While performing the test Standing on one leg with eyes closed, the group of obese examinees did not lag behind the scores of other groups. The lowest average score in this test was achieved by the group of malnourished people. But this result was not statistically very different from other groups. The group of obese people had statistically significantly lower scores in the tests in which repetitive strength of the trunk muscles, statistical force of arms and shoulders and explosive strength of the legs were evaluated. This raises the question of the relation of these basic motor abilities in obese persons. The studies (Hue, Berrigan, Simoneau, Marcotte, Marceau, Marceau, \& Teasdale, 2008) show that hypocaloric diet, which leads to the reduction of $11 \%$ of weight, causes $10 \%$ of the muscle strength reduction of the lower extremities. It means that the programs which lead to weight loss and which do not contain the activities which would influence the increase in the strength of postural muscles, reduce the effects caused by weight loss and do not lead to significant improvement of balance. In another study (Handrigan, Hue, Simoneau, Corbeil, Marceau, Marceau, \& Teasdale, 2010) it has been shown that the loss of weight, even when it is connected with the loss of strength, leads to the improvement of postural stability.

\section{The Relationship between BMI and Test Scores for the Evaluation of Precision}

Recent studies indicate that obese children have bad balance. It is questioned how much the weaker postural stability influences other motor abilities. The aim of the study conducted by Berrigan, Simoneau, Tremblay, Hue, and Teasdale (2006) was to determine if obesity limits the speed of precision of movement performance of upper extremities in upright position. The task was, after hearing an auditory signal, to put nails into small holes which were different in size (in the span from $0.5 \mathrm{~cm}$ to $5 \mathrm{~cm}$ in diameter) and were placed at a distance from 0 to $30 \mathrm{~cm}$ from the examinee. The speed of arm movement was measured. The movement of the leaning center in foot was measured while performing the motor task, and the speed and amplitude of the movement of different body segments which participate in performing the motor task were also measured. It was stated that the leaning center in feet in obese children was shifted $2.7 \mathrm{~cm}$ forward in comparison with normally nourished group by reducing target signs and enlarging the distance at which the nails were put. The differences in precision between the obese children and normally nourished ones became bigger. The difference in movement biomechanics was also recorded. The obese examinees were moving forward with their whole body while putting the nails into the holes, 
whereas the examinees with normal BMI were doing this more economically, only by arm movement, stretching in elbow joint and flexing in shoulder joint. While working on the smallest targets, the precision of the obese examinees was the worst and the movements were slower, about 150-145 milliseconds on average. In the conclusion the authors stated that obese people have a reduced precision of performing arm movements because of the problems in keeping and controlling the balance. In the present study, no statistical difference was found between the groups in the tests in which precision was evaluated. In the test for the evaluation of precision (the Darts) the group of obese examinees achieved 2.8 points in the target. This is the worst average score of all groups, who achieved the following scores: malnourished -4.30 ; normally nourished - 5.18; pre-obese -5.11 . Because of this, we can ask a question whether these differences would increase if the target was smaller or if the target was set at a greater distance.

\section{The Relationship between BMI and the Test Scores for the Evaluation of Coordination}

The relationship between obesity and coordination is not completely clear, because the findings in different studies are controversial. It is possible that the existing differences in the research results are a consequence of differences in methodological approach since different tests for the evaluation of coordination and the results are applied, which are not sufficiently discriminative (D'Hondt et al., 2009). Besides, coordination is a multidimensional space which, thanks to different processes in the organism (neuropsychological, anatomical, psychological, functional and biochemical) enables numerous motor functions. Because of its latent structure, coordination cannot be measured directly, but the evaluation is done by the use of dozens of different standardized motor tests. Because of the complexity of the problem and insufficiently developed scientific methodology, there has been no general attitude if there is a unique body coordination or it can be segmentary, which would in that case condition the existence of coordination of upper and lower extremities. Besides this, it is not really clear if the coordination combines the balance and precision, or whether there are two independent motor abilities. Because of these unresolved issues, dozens of different tests and measuring instruments have been standardized up to now, which significantly complicates the evaluation of this motor ability.

By analyzing the former studies, we get the impression that obese people fall behind in coordination in comparison to normally nourished people (Pelemiš, 2016). According to Gentier, D'Hondt, Shultz, Deforche, Augustijn, Hoorne, and Lenoir (2013), the reasons for such findings are that obese people have problems with integration and the processing of sensor information, which appears as a consequence of the damage functioning of perceptive gestalt motor functions. The thing that appears as the general statement in most studies is that, if fine motor precision, arm coordination and the movements in which the skill for the control of objects are 
preformed, like the movement of the coins, then there are no essential differences (Southall, Okely, \& Steele, 2004). However, if the coordination which demands the engagement of bigger body segments or the movement of the whole body is evaluated, then obese people achieve low scores (D' Hondt et al., 2013).

In the tests applied in this research to evaluate coordination (Twenty steps with moving through the sticks and Bouncing of a ball) there were no statistically significant differences between the groups although the group of obese examinees achieved the lowest average score. The reasons why there was no significant difference in coordination in favor of normally nourished can be probably explained by the composition of motor tasks applied during the testing. In both tests it was necessary to manipulate the objects (ball, stick) in the exactly determined way. In other studies in which the evaluation of coordination should have been done through the control of objects, for example of coins, there were no essential differences between the scores achieved by normally nourished or obese persons (Okely, Booth, \& Chey, 2004). The choice of the test for whose realization it would be necessary to perform movements by the whole body in longer distance like the test Obstacle course backwards, Stick agility with jumping and Obstacle course with jumping and moving through, could cause different test scores.

\section{The Relationship between BMI and the Test Scores for the Evaluation of Strength and Force}

A group of obese boys achieved statistically lower scores in these tests: Long jump, Stretching of the trunk and Hanging pull-ups. These are the tests for the evaluation of the explosive strength of lower extremities, repetitive strength of back muscles and statistical force of bending muscles in elbow joint. As we have seen, low scores were achieved in $20 \mathrm{~m}$ running and $30 \mathrm{~m}$ running tests, which, besides speed, also test explosivity of lower extremity muscles. The similar scores were obtained by Castetbon and Anreyeva (2012), who found that the scores of obese preschoolers in the test Long jump (1.7 inches on average) were $20 \%$ lower in comparison to normally nourished children. The study conducted by Graf, Koch, Kretschmann-Kandel, Falkowski, Christ, Coburger, and Predel (2004) compared motor coefficients of obese and normally nourished children. Motor coefficient was achieved by some of the scores achieved in three tests (Obstacle course backwards, Single-leg hurdle jump and Side movement). The authors think that locomotor competences of this type are directly connected with overweight and disturbed muscular skeleton functions in obese children. Deforche, De Bourdeaudhuij, D’Hondt, and Cardon (2009) reported similar findings obtained with Eurofit battery of tests, which evaluated motor abilities of obese and non-obese young people aged between 12 and 18 years.

On the basis of the findings obtained in this research we consider that the scores are such because of insufficient standardization of the tests which are used in research, which is in accordance with the research by Šekeljić, Stamatović, Marković, and 
Marković (2013). Because of the way in which these motor tasks are performed and the way in which speed, agility, strength and muscle force are evaluated, it can be said that these tests (except Dynamometry of a hand) are standard (they are performed in the same, determined way), but they are not standardized (load in working units is not the same for the examinees with different body mass). In order for the test to be standardized it is necessary that outward (mechanical) work is the same for all examinees, which is not the case in these tests. Outward work, according to the basic law of mechanics, depends on body mass. That is why the performed mechanical work for the examinees of different body mass is different. According to the second Newton law, the force is equal to the product of mass and acceleration $(\mathrm{F}=\mathrm{m} \times \mathrm{a})$. In the international system of measurement units, the newton is a unit of force and is defined as the quantity of force needed for the acceleration of the mass of $1 \mathrm{~kg}$ through $1 \mathrm{~m}$ in square second $\left(1 \mathrm{~N}=\mathrm{kgm} / \mathrm{s}^{2}\right)$. However, the newton is also a unit of weight. The Earth attracts all bodies towards its centre by the force of gravity. Because of that all bodies press the floor on which they lean. The total pressure of the body on the horizontal floor on which it stands or traction by which the gravity force acts on body while hanging is called bodyweight. On the Earth's surface, the score of acting of gravity force on the body is constant $-\mathrm{g}=9.81 \mathrm{~m} / \mathrm{s}^{2}$, and it is usually rounded to the value of $10 \mathrm{~m} / \mathrm{s}^{2}$. Bodyweight $(\mathrm{Q})$ is proportional to the body mass and gravity force $(\mathrm{Q}=\mathrm{m} \times \mathrm{g})$, and that is why the body of $1 \mathrm{~kg}$ mass weighs about $10 \mathrm{~N}$. During free fall the body mass gets acceleration under the influence of gravity force. Because of that, if we put the value of gravity acceleration "g" in the unit of force $(\mathrm{F}=\mathrm{m} \times \mathrm{a})$ instead of acceleration "a", the value for force $F$ is called weight. So, bodyweight $(\mathrm{Q})$ is equal to the product of mass $(\mathrm{m})$ and the Earth gravity force $(\mathrm{g})$. Because of this, these tests are only standard (because the protocol of performing the test is the same), but they are not standardized, because the force which the persons with different mass apply in tests is not the same. As a support to this statement there are scores which show that a group of obese examinees did not have a lower score in the test Dynamometry of a hand. In this test it was necessary to press the dynamometer as strongly as possible, and the demonstrated force did not depend on the body mass or gravity force.

The research carried out by Markovic and Jaric (2004) showed that the body mass is important in testing the physical performance and that certain tests are applied inadequately. The research confirms (Jaric, 2003) the classification of physical performances on the basis of the body mass during the testing of certain motor performances. In fact, the authors state that, while testing the tension of the outer force (lifting of own body, pushing or moving) in the tests of fast movement (jumping and sprint running), it is necessary to take into consideration the role of alometric relation between the tested performances and body mass indices. The standardization of the tests would be implemented by the application of alometric relation, which would be calculated by the formula $\mathrm{Pn}=\mathrm{P} / \mathrm{Sb}$, where $\mathrm{P}$ stands for the tested performance, and $\mathrm{Sb}$ marks the body mass index. 


\section{Conclusion}

Considering the scope of the problem and the consequences which obesity can cause, the strategic goal of each nation should be the promotion of moderate physical activity and development of healthy life routines which would contribute to the prevention of obesity and make timely influence on the development of motor abilities. If the intervention is not adequate and timely, this problem will further progress in an already seen pattern. Reduced physical activity worsens the problems with obesity. It enhances the risk of many diseases which are the consequence of reduced physical activity and obesity. Because of this fact, attention should be paid, especially in kindergartens and schools, to interdisciplinary cooperative conceptions in order to achieve long-lasting effects on changing the unhealthy habits. The interventions would be based on the improvement of the real and perceived physical competence of overweight children, through different modeling of physical activities with the goal of studying and mastering the basic motor skills and improving motor abilities.

Some future studies should be carried out on the representative sample for the whole Serbia. This research should be longitudinal, with carefully chosen motor tests which would not give favor to normally nourished persons, as is the case with most of the tests for the evaluation of strength. Besides, along with the study of motor dimension scanning of the examinees' postural status, it is necessary to determine anatomic and biomechanical causes of motor inadequacy. The detailed insight in relationships between BMI, motor abilities, posture and other complementary factors will indicate the real reasons of motor ability inadequacy, and it will shed light on the methods which will be used as a goal of prevention and then on removing unfavorable consequences of obesity.

\section{References}

Aycan, Z. (2009). Obesity in childhood: definition and epidemiology. Journal of Clinical Research in Pediatric Endocrinology, 1(S1), 44-53. https://doi.org/10.4008/jcrpe.v1i1.25

Berrigan, F., Simoneau, M., Tremblay, A., Hue, O., \& Teasdale, N. (2006). Influence of obesity on accurate and rapid arm movement performed from a standing posture. International Journal of Obesity, 30(12), 1750-1757. https://doi.org/10.1038/sj.ijo.0803342

Castetbon, K., \& Andreyeva, T. (2012). Obesity and motor skills among 4- to 6-year-old children in the United States: Nationally representative surveys. BioMed Central Pediatrics, 12(1), 28. https://doi.org/10.1186/1471-2431-12-28

Close, J. C., Lord, S. L., Menz, H. B., \& Sherrington, C. (2005). What is the role of falls?. Best Practice \& Research Clinical Rheumatology, 19(6), 913-935. https://doi.org/10.1016/j. berh.2005.06.002 
Corbeil, P., Simoneau, M., Rancourt, D., Tremblay, A., \& Teasdale, N. (2001). Increased risk for falling associated with obesity: mathematical modeling of postural control. IEEE Transactions on Neural Systems and Rehabilitation Engineering, 9(2), 126-136. https://doi. org/10.1109/7333.928572

Deforche, B., De Bourdeaudhuij, I., D’Hondt, E., \& Cardon, G. (2009). Objectively measured physical activity, physical activity related personality and body mass index in 6- to 10-yearold children: a cross-sectional study. International Journal of Behavioral Nutrition and Physical Activity, 25(6),1-9. https://doi.org/10.1186/1479-5868-6-25

D’Hondt, E., Deforche, B., De Bourdeaudhuij, I., \& Lenoir, M. (2008). Childhood obesity affects fine motor skill performance under different postural constraints. Neuroscience Letters, 44(1), 72-75. https://doi.org/10.1016/j.neulet.2008.05.056

D’Hondt, E., Deforche, B., De Bourdeaudhuij, I., \& Lenoir, M. (2009). Relationship between motor skill and body mass index in 5- to 10-year-old children. Adapted Physical Activity Quarterly, 26(1), 21-37. https://doi.org/10.1123/apaq.26.1.21

D’Hondt, E., Deforche, B., Gentier, I., De Bourdeaudhuij, I., Vaeyens, R., Philippaerts, R., \& Lenoir, M. (2013). A longitudinal analysis of gross motor coordination in overweight and obese children versus normal-weight peers. International Journal of Obesity, 37(1), 61-67. https://doi.org/10.1038/ijo.2012.55

Dowling, A. M., Steel, J. R., \& Baur, L. A. (2004). What are the effects of obesity in children on plantar pressure distributions? International Journal of Obesity, 28(11), 1514-1519. https:// doi.org/10.1038/sj.ijo.0802729

Đokić, Z., \& Međedović, B. (2013). Povezanost prekomerne uhranjenosti i gojaznosti sa motoričkim sposobnostima dece od 9-12 godina. Fizička kultura, 67(2), 91-102. https:// doi.org/10.5937/fizkul1302091D

Gentier, I., D’Hondt, E., Shultz, S., Deforche, B., Augustijn, M., Hoorne, S., \& Lenoir, M. (2013). Fine and gross motor skills differ between healthy-weight and obese children. Research in Developmental Disabilities, 34(11), 4043-4051. https://doi.org/10.1016/j.ridd.2013.08.040

Graf, C., Koch, B., Kretschmann-Kandel, E., Falkowski, G., Christ, H., Coburger, S., \& Predel, H. G. (2004). Correlation between BMI, leisure habits and motor abilities in childhood (CHILT-project). International Journal of Obesity, 28(1), 22-26. https://doi.org/10.1038/ sj.ijo.0802428

Handrigan, G., Hue, O., Simoneau, M., Corbeil, P., Marceau, P., Marceau, S., \& Teasdale, N. (2010). Weight loss and muscular strength affect static balance control. International Journal of Obesity, 34(5), 936-942. https://doi.org/10.1038/ijo.2009.300

Hue, O., Berrigan, F., Simoneau, M., Marcotte, J., Marceau, P., Marceau, S., \& Teasdale, N. (2008). Muscle force and force control after weight loss in obese and morbidly obese men. Obesity Surgery, 18(9), 1112-1118. https://doi.org/10.1007/s11695-008-9597-5

Jaric, S. (2003). Role of body size in the relation between muscle strength and movement performance. Exercise and Sport Science Reviews, 31(1), 8-12. https://doi. org/10.1097/00003677-200301000-00003

Jovanović, R., Nikolovski, D., Radulović, O., \& Novak S. (2010). Physical activity influence on nutritional status of preschool children. Acta Medica Medianae, 49(1), 17-21. 
Kurelić, N., Momirović, K., Stojanović, M., Radojević, Ž., \& Viskić-Štalec, N. (1975). Struktura i razvoj morfoloških i motoričkih dimenzija omladine. Beograd: Institut za naučna istraživanja Fakulteta za fizičko vaspitanje Univerziteta u Beogradu.

Li, X., \& Aruin, A. S. (2007). The effect of short-term changes in the body mass on anticipatory postural adjustments. Experimental Brain Research, 181(2), 333-346. https:// doi.org/10.1007/s00221-007-0931-2

Logan, S. W., Scrabis-Fletcher, K., Modlesky, C., \& Getchell, N. (2011). The relationship between motor skill proficiency and body mass index in preschool children. Research Quarterly for Exercise and Sport, 82(3), 442-448. https://doi.org/10.1080/02701367.201 $\underline{1.10599776}$

Mandić, D., Martinović, D., \& Pelemiš, V. (2017). Structure of motor abilities of pre-school children before and after kinesiology treatment. Croatian Journal of Education, 19(Sp. Ed.No.2), 155-169. https://doi.org/10.15516/cje.v19i0.2733

Markovic, G., \& Jaric, S. (2004). Movement performance and body size: the relationship for different groups of tests. European Journal of Applied Physiology, 92(1-2), 139-149. https:// doi.org/10.1007/s00421-004-1076-7

Martinović, D., \& Pelemiš, V. (2015). Kinantropološki aspekti učenika. Beograd: Draslar partner.

Morano, M., Colella, D., \& Caroli, M. (2011). Gross motor skill performance in a sample of overweight and non-overweight preschool children. Pediatric Obesity, 6(S2), 42-46. https:// doi.org/10.3109/17477166.2011.613665

Muehlbauer, T., Gollhofer, A., \& Granacher, U. (2012). Relationship between measures of balance and strength in middle-aged adults. The Journal of Strength \& Conditioning Research, 26(9), 2401-2407. https://doi.org/10.1519/JSC.0b013e31823f8c41

Okely, A. D., Booth, M. L., \& Chey, T. (2004). Relationships between body composition and fundamental movement skills among children and adolescents. Research Quarterly for Exercise and Sport, 75(3), 238-247. https://doi.org/10.1080/02701367.2004.10609157

Pelemiš, V. (2016). Uticaj dodatnog programa fizičkog vežbanja na morfološki i motorički status predškolske dece (Doctoral dissertation). Novi Sad: Fakultet sporta i fizičkog vaspitanja Univerziteta u Novom Sadu.

Pelemiš, V., Branković, P., \& Banović, M. (2016). State Nutrition of Pre-School Children. Sports Science and Health, 6(2) 129-134

Pelemiš, V., Macura, M., \& Branković, P. (2017). Sex differences in morphological characteristics of preschool children. The Anthropologist, 30(2), 153-160.

Peterkova, V., \& Kosigina, A. (2011). Doktrina i iskustvo programa prevencije i lečenja gojaznosti kod adolescenata u ruskoj federaciji. Medicinski glasnik Specijalna bolnica za bolesti štitaste žlezde i bolesti metabolizma Zlatibor, 16(39), 78-84. https://doi.org/10.5937/ medgla1139078P

Prskalo, I. (2015). Kinesiology of Free Time. Croatian Journal of Education, 17(1), 219-228. https://doi.org/10.15516/cje.v17i0.1520

Prskalo, I., Horvat, V., \& Hraski, M. (2014). Play and Children's Kinesiological Activities: A Precondition for Making Daily Exercise a Habit. Croatian Journal of Education, 16(1), 57-68. 
Rosner, B., Prineas, R., Loggie, J., \& Daniels, S. R. (1998). Percentiles for body mass index in US children 5 to 17 years of age. The Journal of Pediatrics, 132(2), 211-222. https://doi. org/10.1016/S0022-3476(98)70434-2

Sarkar, A., Singh, M., Bansal, N., \& Kapoor, S. (2011). Effects of obesity on balance and gait alterations in young adults. Indian Journal of Physiology and Pharmacology, 55(3), 227-233.

Šekeljić, G., Stamatović, M., Marković, Z., \& Marković, J. (2013). Metric characteristics of the motor test used to estimate the force of arms and shoulders. Facta Universitatis series: Physical Education and Sport, 11(1), 115-124.

Southall, J. E., Okely, A. D., \& Steele, J. R. (2004). Actual and perceived physical competence in overweight and nonoverweight children. Pediatric Exercise Science, 16(1), 15-24. https:// doi.org/10.1123/pes.16.1.15

Sporiš, G., Badrić, M., \& Miljković, Z. (2014). Do the overweight and obesity effect on motor ability level among girls? Sport Science, 7(2), 36-43.

Taylor, E. D., Theim, K. R., Mirch, M. C., Ghorbani, S., Tanofsky-Kraff, M., Adler-Wailes, D. C., \& Yanovski, J. A. (2006). Orthopedic complications of overweight in children and adolescents. Pediatrics, 117(6), 2167-2174. https://doi.org/10.1542/peds.2005-1832

Teasdale, N., Simoneau, M., Corbeil, P., Handrigan, G., Tremblay, A., \& Hue, O. (2013). Obesity alters balance and movement control. Current Obesity Reports, 2(3), 235-240. https://doi.org/10.1007/s13679-013-0057-8

Wang, Y., \& Lobstein, T. I. M. (2006). Worldwide trends in childhood overweight and obesity. Pediatric Obesity, 1(1), 11-25. https://doi.org/10.1080/17477160600586747

Wearing, S. C., Hennig, E. M., Byrne, N. M., Steele, J. R., \& Hills, A. P. (2006). The impact of childhood obesity on musculoskeletal form. Obesity Reviews, 7(2), 209-218. https://doi. org/10.1111/j.1467-789X.2006.00216.x

World Health Organization. (2000). Obesity: preventing and managing the global epidemic (No. 894). World Health Organization.

Yusof, S. M., Aiman, S., Zawi, M. K., Hasan, H., \& Radzi, A. A. M. (2013). Body composition index predict children's motor skills proficiency. International Journal of Medical and Health Sciences 7(7), 395-401.

Živić, S., Ćirić, V., \& Stanković, S. (2011). Epidemiološke karakteristike i etiopatogeneza gojaznosti dece i adolescenata. Medicinski glasnik Specijalna bolnica za bolesti štitaste žlezde i bolesti metabolizma Zlatibor, 16(39), 40-49. https://doi.org/10.5937/medgla1139040Z

\section{Goran Šekeljić}

Faculty of Education, University of Kragujevac

Jovana Cvijića bb, Kragujevac, Serbia

gsekeljic@sbb.rs

\section{Milovan Stamatović}

Faculty of Education, University of Kragujevac

Jovana Cvijića bb, Kragujevac, Serbia

stamatovic@ucfu.kg.ac.rs 


\section{Dragan Martinović}

Faculty of Teacher Education, University of Belgrade

Kraljice Natalije 43, Belgrade 11000, Serbia

dragan.martinovic@uf.bg.ac.rs

\section{Vladan Pelemiš}

Faculty of Teacher Education, University of Belgrade

Kraljice Natalije 43, Belgrade 11000, Serbia

vladan.pelemis@uf.bg.ac.rs 


\section{Komparativna studija motoričke izvedbe dječaka s različitim indeksima tjelesne mase}

\section{Sažetak}

Cilj je ovoga istraživanja usporediti motoričke sposobnosti dječaka s različitim indeksima tjelesne mase i odrediti jesu li djeca pretila ili imaju prekomjernu tjelesnu težinu te u kojoj su mjeri njihove motoričke vještine nedovoljno razvijene, u usporedbi s normalno uhranjenom djecom. Uzorak ispitanika sastojao se od 180 učenika četvrtoga razreda, u dobi od 10 godina ( \pm 6 mjeseci), iz pet osnovnih škola iz Užica (Republika Srbija). Na temelju rezultata indeksa tjelesne mase (BMI) uzorak je podijeljen na četiri poduzorka: slabo uhranjenu djecu $(N=30)$, normalno uhranjenu djecu $(N=90)$, djecu s prekomjernom tjelesnom težinom $(N=30)$ i pretilu djecu $(N=30)$. Procjena devet motoričkih sposobnosti provedena je s pomoću baterije od 18 testova. Ispitanici iz skupine slabo uhranjene djece (AW) postigli su najlošiji rezultat na 7 od 18 testova. Skupina normalno uhranjene djece (NW) nije postigla najlošiji prosječni rezultat ni na jednom testu, a u 10 od 18 testova imali najbolji prosječan rezultat. Skupina djece s prekomjernom tjelesnom težinom (OW) postigla je najbolji prosječni rezultat na 8 od 18 testova. Skupina pretilih ispitanika (OB) postigla je najlošiji prosječni rezultat na 11 od 18 testova te nisu imali najbolji prosječan rezultat ni na jednom testu. Rezultati istraživanja pokazuju da skupina djece s prekomjernom tjelesnom težinom i skupina pretile djece imaju određenih problema u motoričkoj dimenziji u segmentu koji je povezan s pokazivanjem mišićne jačine i snage, u segmentu postizanja brzine i segmentu ravnoteže.

Ključne riječi: indeks tjelesne mase; motoričke sposobnosti; pretilost; razlike.

\section{Uvod}

Tendencija povećane učestalosti prekomjerne tjelesne težine i pretilosti u djece postala je čest problem većine zemalja. U djece i adolescenata pretilost se definira kao povećanje tjelesne mase iznad referentnih vrijednosti koje su određene za spol, dob i tjelesnu visinu, a rezultat je povećana količina masti u organizmu (Pelemiš, Macura i Branković, 2017). Postoji nekoliko oblika pretilosti: „obična“, konstitucijska, pretilost uzrokovana poremećajem u radu hipotalamusa i ona uzrokovana nekim sindromima (Peterkova i Kosigina, 2011). Količina masnoga tkiva može se procijeniti na nekoliko 
načina: mjerenjem debljine nabora potkožnoga masnog tkiva, s pomoću indeksa tjelesne mase (BMI), bioelektričnom impedancijom i metodom razrjeđivanja vodom, iako su poznate i neke subjektivne metode, poput metode siluete. U svakodnevnom životu razina pretilosti najčešće se procjenjuje na temelju indeksa tjelesne mase (BMI), koji predstavlja kvocijent tjelesne mase (kg) i kvadrata tjelesne visine (m). Indeks tjelesne mase koristi se kao alat za provjeru i prepoznavanje mogućih problema s tjelesnom težinom djece (Pelemiš i sur., 2016). Taj način pokazuje zadovoljavajuću razinu korelacije izravnog mjerenja sadržaja tjelesne masti u odraslih osoba, ali i u djece (Rosner, Prineas, Loggie i Daniels, 1998), s debljinom kožnih nabora tricepsa i struka (Jovanović, Nikolovski, Radulović i Novak, 2010). Istraživanje (Aycan, 2009) je pokazalo da je u prvome desetljeću 21. stoljeća širom svijeta stopa pretilosti narasla za $6 \%$, u svim dobnim skupinama. Problem s prekomjernom tjelesnom težinom pojavljuje se u ranoj dječjoj dobi i smatra se da danas više od $10 \%$ svjetske populacije školske dobi ima prekomjernu tjelesnu težinu (Martinović i Pelemiš, 2015). Prema podacima Svjetske zdravstvene organizacije (WHO, 2000) u SAD-u je 2000. godine bilo $20 \%$ pretilih odraslih osoba, a procjenjuje se da ih je 2015. bilo 30\%. Predviđa se da će ih u 2025. godini biti više od 40\%. Prema podacima Međunarodne radne skupine za pretilost Srbija je 2005. godine bila gotovo na vrhu popisa zemalja s porastom pretilosti u djece (Wang i Lobstein, 2006). Problem pretilosti očitiji je u odraslih osoba (Živić, Ćirić i Stanković, 2011) zato što je 2000. godine više od polovine ukupnoga stanovništva Srbije imalo problema s tjelesnom težinom. Točnije, $54 \%$ odraslih osoba ima prekomjernu tjelesnu težinu, od toga ih $36,7 \%$ pripada skupini osoba koje bi mogle postati pretile, a njih $17,3 \%$ već pripada kategoriji pretilih osoba. Procjenjuje se da je učestalost pretilosti u djece u Srbiji 19\%.

Osim činjenice da pretilost predstavlja opasnost za zdravlje i da utječe na daljnje smanjenje tjelesne aktivnosti, rezultati istraživanja (Sarkar, Singh, Bansal i Kapoor, 2011) pokazuju da prekomjerna tjelesna težina vodi nedovoljnoj motoričkoj razvijenosti, slabijim motoričkim sposobnostima i vještinama, što općenito gledajući može imati negativan utjecaj na cjelokupan motorički razvoj. Djeca s niskom razinom motoričkih sposobnosti manje sudjeluju u tjelesnim aktivnostima i u manjoj se mjeri uključuju u sportove ili organizirane igre. Za razliku od njih osobe koje su u djetinjstvu bolje razvile motoričke sposobnosti, bit će aktivnije u adolescenciji (Mandić, Martinović i Pelemiš, 2017; Morano, Colella i Caroli, 2011).

Motoričke sposobnosti omogućavaju sve ljudske aktivnosti. Motoričke sposobnosti koje zbog bilo kojega razloga nisu adekvatno razvijene, vode smanjenoj motoričkoj angažiranosti djece, što općenito doprinosi nižoj razini tjelesne aktivnosti, slabijim motoričkim vještinama i nakupljanju masnoga tkiva. Posljedica su toga i zdravstveni problemi, problemi u načinu na koji mladi ljudi vide sami sebe, kao i različiti problemi u socijalizaciji. Pretilost utječe na smanjenje fizičke aktivnosti na nastavi Tjelesne i zdravstvene kulture, ali i na smanjenje fizičke aktivnosti u slobodno vrijeme (Prskalo, 2015). Vrtići i škole, u suradnji sa zdravstvenim institucijama, trebali bi odrediti 
fizičke aktivnosti prilagođene pretilim osobama kako bi ih motivirale za sudjelovanje $\mathrm{u}$ raznim sportovima, smanjile razlike u osnovnim motoričkim sposobnostima i razvile interes za društvene interakcije. Prevencija nedovoljno razvijene motoričke dimenzije jako je bitna jer na taj način sva djeca dobivaju istu priliku za uspješan razvoj (Prskalo, Horvat i Hraski, 2014). Ovo bi istraživanje trebalo dati odgovor na pitanje koje kategorije statusa uhranjenosti djece doprinose boljoj izvedbi motoričkih vještina, jer ne postoje dokazi da su takva istraživanja provedena na teritoriju Republike Srbije. Takvi bi rezultati mogli omogućiti bolje planiranje nastavnih sadržaja u Tjelesnoj i zdravstvenoj kulturi kao školskome predmetu.

Ovo je istraživanje provedeno s ciljem usporedbe motoričkih sposobnosti dječaka koji su, prema prihvaćenim standardima, svrstani u kategorije slabo uhranjene djece, normalno uhranjene djece, djece s prekomjernom tjelesnom težinom i pretile djece. Stoga se može reći da je cilj ove studije bio usporediti motoričke sposobnosti dječaka različitih indeksa tjelesne mase i utvrditi pokazuju li pretila djeca ili ona s prekomjernom tjelesnom težinom, i u kojoj mjeri, motoričku nerazvijenost kada se usporede s normalno uhranjenom djecom.

\section{Metode}

Uzorak u istraživanju sastojao se od 180 učenika četvrtoga razreda, u dobi od 10 godina ( \pm 6 mjeseci), iz pet osnovnih škola u Užicama (Republika Srbija). Na temelju rezultata vrijednosti indeksa tjelesne mase ispitanika uzorak je podijeljen na četiri poduzorka: slabo uhranjenu djecu $(\mathrm{N}=30)$, normalno uhranjenu djecu $(\mathrm{N}=90)$, djecu s prekomjernom tjelesnom težinom $(\mathrm{N}=30)$ i pretilu djecu $(\mathrm{N}=30)$. Indeks tjelesne mase predstavlja kvocijent tjelesne mase ( $\mathrm{kg})$ i kvadrata tjelesne visine (m). Prema podacima Svjetske zdravstvene organizacije (2000) ispitanici čiji je indeks tjelesne mase bio ispod 18,5 bili su svrstani u skupinu slabo uhranjene djece; oni čiji je indeks tjelesne mase bio između 18,5 i 24,9 bili su svrstani u skupinu normalno uhranjene djece; oni čiji je indeks tjelesne mase bio između 25 i 29,9 bili su svrstani u skupinu djece s prekomjernom tjelesnom težinom, a ispitanici s indeksom tjelesne mase iznad 30 bili su svrstani u skupinu pretilih.

Procjena devet motoričkih sposobnosti provedena je s pomoću baterije od 18 testova koje su upotrebljlavalii Kurelić, Momirović, Stojanović, Radojević i Viskić-Štalec (1975). Eksplozivna snaga procijenjena je s pomoću dvaju testova - skokom udalj s mjesta $(\mathrm{cm})$ i bacanjem medicinke $(\mathrm{cm})$; repetitivna snaga procijenjena je testovima podizanja trupa za 30 sekundi (frekvencija) i istezanjem trupa (frekvencija), a statička snaga procijenjena je s pomoću testova izdržaj u visu zgibom (sek) i dinamometrija ruke (kp). Brzina sprinta procijenjena je testovima sprint iz visokog starta na $20 \mathrm{~m}$ i trčanje $30 \mathrm{~m}$ startom u mjestu (sek), a segmentarna brzina procijenjena je s pomoću tapinga rukom (frekvencija) i tapinga nogama (frekvencija). Fleksibilnost je procijenjena s pomoću testova duboki pretklon na klupi $(\mathrm{cm})$ i špaga $(\mathrm{cm})$, ravnoteža s pomoću testova stajanje na jednoj nozi sa zatvorenim očima (sek) i stajanje na jednoj nozi na klupici 
poprečno (sek). Koordinacija je procijenjena s pomoću testova 20 koraka s provlačenjem kroz štapove (sek) i bacanje lopte na zid 15 sekundi (frekvencija), preciznost s pomoću testova gadanje u horizontalnu metu malom loptom (frekvencija) i gadanje u vertikalnu metu - pikado (frekvencija).

Važnost razlika između formiranih poduzoraka testirana je s pomoću multivarijatne analize varijance (MANOVA). Kod varijabli kod kojih je ostvarena statistički značajna vrijednost F, „LSD“ post hoc test koristio se u daljnjoj analizi kako bi se odredile razlike između srednjih vrijednosti skupina. Statistička značajnost testirana je na razini značajnosti od $\mathrm{p}<0,05$. Svi su podaci analizirani s pomoću IBM SPSS (verzija 19.0) statističkog računalnog programa za Windowse.

\section{Rezultati}

Rezultati (MANOVA) ( $\mathrm{F}=2,010 ; \mathrm{p}=0,000)$ pokazuju da u multivarijatnom okruženju postoje statistički značajne razlike među varijablama za procjenu motoričkih sposobnosti u skupinama ispitanika. Rezultati jednosmjerne analize varijance (ANOVA) (Tablica 1) pokazuju da postoji statistički značajna razlika između skupina, i to $\mathrm{u}$ varijabli (skok udalj: $\mathrm{f}=10,360, \mathrm{p}=0,000$; podizanje trupa: $\mathrm{f}=2,830, \mathrm{p}=0,041$; istezanje trupa: $\mathrm{f}=2,545, \mathrm{p}=0,042$; izdržaj u visu zgibom: $\mathrm{f}=8,977, \mathrm{p}=0,000$; trčanje $20 \mathrm{~m}$ : $\mathrm{f}=9,652, \mathrm{p}=0,000$; trčanje $30 \mathrm{~m}: \mathrm{f}=6,530, \mathrm{p}=0,000$; stajanje na jednoj nozi na klupici poprečno: $\mathrm{f}=2,432, \mathrm{p}=0,050$ ).

Analiza statističkih parametara (Tablica 1 ) pokazuje da su ispitanici iz skupine slabo uhranjene djece $(\mathrm{AW})$ postigli najslabije rezultate na 8 od 18 testova: bacanju medicinke, podizanju trupa, dinamometriji ruke, tapingu rukom, špagi, stajanju na jednoj nozi sa zatvorenim očima i bacanju lopte. Ta skupina ispitanika nije postigla najbolji prosječni rezultat ni na jednom testu. Samo su u testovima podizanje trupa i stajanje na jednoj nozi na klupici poprečno postigli rezultate koji su bili statistički lošiji, i to samo u usporedbi sa skupinom normalno uhranjene djece.

Skupina normalno uhranjenih (NW) ispitanika nije postigla najslabiji rezultat ni na jednom testu. Ta je skupina ostvarila najbolji prosječni rezultat na 10 od 18 testova (skok udalj, podizanje trupa, istezanje trupa, izdržaj u visu zgibom, trčanje $20 \mathrm{~m}$, trčanje $30 \mathrm{~m}$, taping rukom, duboki pretklon, stajanje na jednoj nozi sa zatvorenim očima i pikado).

Skupina ispitanika s prekomjernom tjelesnom težinom (OW) nije postigla najslabiji prosječni rezultat ni na jednom od testova, a na 8 od 18 testova (bacanju medicinke, dinamometriji ruke, tapingu rukom, špagi, stajanju na jednoj nozi na klupici, bacanju lopte i gađanju horizontalne mete) postigla najbolji prosječni rezultat. Na testovima podizanja trupa i stajanju na jednoj nozi na klupici postigli su rezultate koji su bili statistički značajnije lošiji od rezultata skupine normalno uhranjene djece.

Skupina pretilih ispitanika (OB) postigla je najslabije rezultate na 11 od 18 testova (skoku udalj, dubokom pretklonu, trčanju $20 \mathrm{~m}$, trčanju $30 \mathrm{~m}$, tapingu nogama, stajanju na jednoj nozi na klupici, povlačenju štapa, gađanju horizontalne mete i 
pikadu). Ta skupina nije postigla najbolji prosječni rezultat ni na jednom testu, u usporedbi s ostalim skupinama ispitanika. Statistički, oni su bili lošiji na sljedećim testovima: skoku udalj, istezanju trupa, podizanju trupa, trčanju $20 \mathrm{~m}$, trčanju $30 \mathrm{~m}$, stajanju na jednoj nozi na klupici).

Tablica 1

\section{Rasprava}

Rezultati ove studije pokazuju da kod pretile djece postoji znatno manja razina motoričkih sposobnosti. Ti su rezultati u skladu s rezultatima studija (Đokić i Međedović, 2013; Gentier, D’Hondt, Shultz, Deforche, Augustijn, Hoorne, i Lenoir, 2013) koje pokazuju zaostajanje u razvoju motoričkih sposobnosti u pretilih osoba. Ispitivanjem navika djece uočeno je da neaktivan način života vodi smanjenim motoričkim sposobnostima, kao i prekomjernoj tjelesnoj težini i pretilosti. Normalno uhranjena djeca izvode više motoričkih aktivnosti dnevno, a kako smatraju autori, to je glavni razlog za veći napredak u motoričkoj dimenziji, jer se motoričke sposobnosti djece ne razvijaju samo tijekom rasta i razvoja, nego se uče i razvijaju vježbom (Logan, Scrabis-Fletcher, Modlesky i Getchell, 2012).

\section{Veza između indeksa tjelesne mase i rezultata na testovima za procjenu brzine, agilnosti i eksplozivne snage}

Prema različitim istraživanjima (Yusof, Aiman, Zawi, Hasan i Radzi, 2013) razlozi za nedovoljno razvijenu motoričku dimenziju moraju biti anatomske i fiziološke prirode, jer su to faktori koji određuju motoričke sposobnosti. Autori se vode sljedećom analogijom. Ako su anatomski i fiziološki faktori ključni, onda moraju postojati razlike u morfologiji i strukturi tkiva i organa, jer razlike u motoričkoj dimenziji mogu nastati samo primjenom faktora koji ih određuju. To mišljenje potvrđeno je u mnogim studijama. Na primjer, česta pojava valgus koljena od 20 stupnjeva kod osoba koje imaju prekomjernu tjelesnu težinu i koje su pretile, posljedica je MD kutova, tj. kutova između metafizealnih izraslina i linije tibijalne osi (Wearing, Hennig, Byrne, Steele i Hills, 2006). Skeletalna struktura donjih ekstremiteta mijenja se zbog pretilosti, a promjene se pojavljuju na gležnjevima, stopalima i prstima, koji rastu, šire se i postaju debljima (Sarkar i sur., 2011). Osim što postaju debljima, nemaju dostatnu mineralnu gustoću koja bi mogla uspješno izdržati veće opterećenje, pa se kod pretilih adolescenata znatno češće javlja muskuloskeletalna bol u leđima, kukovima, nogama, koljenima, gležnjevima i stopalima (Taylor, Theim, Mirch, Ghorbani, Tanofsky-Kraff, Adler-Wailes i Yanovski, 2006).

Taj rezultat također je potvrđen u našoj studiji jer su pretili ljudi, statistički gledajući, postigli slabe rezultate na testovima: skok udalj, trčanje $20 \mathrm{~m}$ i trčanje $30 \mathrm{~m}$. To su testovi za procjenu eksplozivne snage donjih ekstremiteta i brzine kretanja, a u znatnoj mjeri ovise o anatomskom i fiziološkom stanju lokomotornog aparata i sustava koji upravlja posturalnom stabilnošću (vestibularni aparat i živčane strukture koje su 
povezane s različitim kinestetičkim receptorima u mišićima, kostima i zglobovima). U testovima koji su se koristili za procjenu segmentarne brzine ekstremiteta (taping rukom i taping nogama) u ovom i još jednom istraživanju (Sporiš, Badrić i Miljković, 2014) nisu uočene razlike među skupinama, jer su tijekom testiranja ispitanici micali manje dijelove tijela pa promjene u držanju nisu značajno utjecale na rezultate testova.

\section{Veza između indeksa tjelesne mase i rezultata na testovima za procjenu ravnoteže}

Problemi u postularnom statusu mogu biti ključni za razumijevanje problema $s$ ravnotežom koje pretili ljudi imaju. Kretnja tijela prema naprijed povećava vrh sile i tako stvara veći moment rotacije sile u centrima rotacija u zglobovima donjih ekstremiteta. Zbog toga se više koriste mišići koji kompenziraju kretnju tijela prema naprijed kako bi se održala ravnoteža (Dowling, Steel i Baur, 2004). Dugoročna upotreba mišića uzrokuje njihovo brže umaranje, što otežava održavanja ravnoteže te objašnjava slabije rezultate pretilih ljudi na testovima ravnoteže. Osim toga, nestabilnost povećava inertnost tijela zbog prekomjerne težine, što znatno otežava funkcioniranje lokomotornog sustava koji upravlja vestibularnim aparatom i kinestetičkim receptorima (D’Hondt, Deforche, De Bourdeaudhuij i Lenoir, 2008). Slabija ravnoteža pretilih ljudi može se objasniti smanjenim dotokom senzornih informacija, a autori smatraju da je gubitak viška tjelesne težine jedino rješenje za bolju kontrolu ravnoteže. Slična istraživanja proveli su i drugi autori, a rezultati i zaključci su slični. Na primjer, u studiji koju su proveli Li i Aruin (2007), ispitanici su bili pod opterećenjem koje je iznosilo između 10\% i 40\% njihove tjelesne mase kako bi se ispitalo hoće li doći do promjena u projekciji točke nagiba i kako će ona utjecati na aktivnost posturalnih mišića. Uočene su promjene u projekciji centra nagiba, a elektromiografija je zabilježila veće kontrakcije mišića trupa i mišića donjih ekstremiteta. Što je opterećenje bilo veće, to su bile i jače kontrakcije mišića. Rezultati upućuju na to da promjene u tjelesnoj masi destabiliziraju tijelo, pa je neophodno da središnji živčani sustav to nadoknadi dodatnom aktivacijom posturalnih mišića kako bi se tijelo stabiliziralo.

Studija je pokazala koliko je mišićne sile potrebno kako bi se pravodobno reagiralo na to da se održi ravnoteža tijela (Corbeil, Simoneau, Rancourt, Tremblay i Teasdale, 2001). Njihovi su izračuni pokazali da pretili ljudi proizvode rotacijski moment u gležnjevima, čak i u malim kretnjama. Ovisno o momentu sile kojom tjelesna težina i gravitacija djeluju na centar rotacije, moguće je izračunati koliko je opterećenje koje gležnjevi podnose. Rezultati pokazuju da je ponekad, kako bi se tijelo održalo u ravnoteži čak i pri izvođenju manjih aktivnosti, potrebno proizvesti toliko mišićne snage koju ispitanici nisu imali, što je dovelo do gubitka ravnoteže i pada.

Oštećena senzorno-motorička i neuromišićna funkcija, uz nedovoljnu snagu mišića, uzrokuje promjene u mehanici pokreta pretilih osoba. Karakterističan obrazac kretanja jest naglašeno uspravno (ukočeno) držanje sa smanjenim savijanjem koljena i kukova. 
Osim toga, karakteristično je i sporo hodanje, sporiji ritam i frekvencija koraka, smanjena duljina koraka i veća širina koraka za 13\% - 42\%. Takvim su osobama potrebne duže pauze i naglašeni periodi potpore na oba stopala, a nastaju i nepotrebne oscilacije u predjelu lubanje. Kut koji zatvaraju longitudinalne linije između stopala (linija koja spaja sredinu pete i drugi nožni prst) veći je kod pretilih ljudi (Close, Lord, Menz i Sherrington, 2005).

Studije provedene na uzorku normalno uhranjenih ljudi iz različitih dobnih skupina pokazuju male korelacije između snage različitih mišićnih skupina i posturalne stabilnosti (Muehlbauer, Gollhofer i Granacher, 2012), što znači da su tve dvije motoričke karakteristike neovisne. $U$ našemu su istraživanju skupina pretilih ispitanika i skupina slabo uhranjenih ispitanika imale statistički značajno lošije rezultate na testu stajanja na jednoj nozi na klupici nego skupina normalno uhranjenih ispitanika. Dok je izvodila test stajanja na jednoj nozi sa zatvorenim očima, skupina pretilih ispitanika nije zaostajala za rezultatima ostalih skupina. Najlošiji prosječni rezultat na tome testu postigla je skupina slabo uhranjenih ispitanika. No, taj rezultat nije statistički znatno drugačiji od rezultata ostalih skupina. Skupina pretilih imala je statistički značajno lošije rezultate na testovima kojima su se procjenjivali snaga mišića trupa, statička snaga ruku i ramena i eksplozivna snaga nogu. To otvara pitanje o vezi između osnovnih motoričkih sposobnosti kod pretilih osoba. Studije (Hue, Berrigan, Simoneau, Marcotte, Marceau, Marceau i Teasdale, 2008) pokazuju da hipokalorijska prehrana, koja vodi smanjenju $11 \%$ tjelesne težine uzrokuje $10 \%$ smanjenja mišićne snage $u$ donjim ekstremitetima. To znači da različiti programi gubitka tjelesne težine koji ne sadrže aktivnosti za jačanje snage posturalnih mišića smanjuju učinak gubitka tjelesne težine i ne vode značajnom poboljšanju u održavanju ravnoteže. U drugom istraživanju (Handrigan, Hue, Simoneau, Corbeil, Marceau, Marceau i Teasdale, 2010) došlo se do spoznaje da gubitak tjelesne težine, čak i kada je povezan s gubitkom snage, vodi poboljšanju posturalne stabilnosti.

\section{Veza između indeksa tjelesne mase i rezultata na testovima za procjenu preciznosti}

Novija istraživanja pokazuju da pretila djeca imaju slabu ravnotežu. Postavlja se pitanje u kojoj mjeri slabija posturalna stabilnost utječe na druge motoričke sposobnosti. Cilj istraživanja koje su proveli Berrigan, Simoneau, Tremblay, Hue i Teasdale (2006) bio je odrediti ograničava li pretilost brzinu preciznosti izvedbe nekoga pokreta gornjih ekstremiteta u uspravnom položaju. Zadatak ispitanika bio je da, nakon što čuju zvučni signal, stave čavle u male rupice koje su bile različitih veličina (u rasponu promjera od $0,5 \mathrm{~cm}$ do $5 \mathrm{~cm}$ ) i koje su bile postavljene na udaljenost od 0 do $30 \mathrm{~cm}$ od ispitanika. Izmjerena je brzina pokreta ruke. Tijekom izvedbe motoričkog zadatka izmjeren je pokret centra nagiba u stopalu. Također su izmjerene brzina i amplituda pokreta različitih dijelova tijela koji su sudjelovali u izvedbi motoričkog zadatka. Uočeno je da se centar nagiba u stopalima pretile djece pomaknuo za 2,7 
$\mathrm{cm}$ prema naprijed u usporedbi sa skupinom normalno uhranjene djece tako što su znakovi za metu smanjeni, a povećana je udaljenost na kojoj su se stavljali čavli. Razlike u preciznosti između pretile djece i normalno uhranjene djece postale su veće. Također je zabilježena i razlika u biomehanici pokreta. Pretili ispitanici naginjali su se prema naprijed cijelim tijelom dok su stavljali čavle u rupice, a ispitanici s normalnim indeksom tjelesne mase to su činili puno ekonomičnije, samo pokretom ruke, istežući ruku u laktu i pomičući rame. Dok su radili na najmanjim metama, preciznost pretilih ispitanika bila je najmanja, a pokreti su bili sporiji - u prosjeku oko 150 do 145 milisekundi. U zaključku autori navode da pretili ljudi imaju smanjenu preciznost izvođenja pokreta rukom zbog raznih problema u održavanju i kontroliranju ravnoteže. U istraživanju nije uočena statistička razlika među skupinama na testovima procjene preciznosti. Na testu procjene preciznosti u pikadu skupina pretilih ispitanika ostvarila je 2,8 bodova u gađanju mete. To je najlošiji prosječni rezultat svih skupina. Rezultati ostalih skupina bili su sljedeći: slabo uhranjeni ispitanici - 4,30 bodova; normalno uhranjeni ispitanici - 5,18 bodova; ispitanici s prekomjernom tjelesnom težinom - 5,11 bodova. Zbog toga se može postaviti pitanje bi li se razlike povećale da je meta bila manja ili da je meta postavljena na većoj udaljenosti.

\section{Veza između indeksa tjelesne mase i rezultata na testovima za procjenu koordinacije}

Veza između pretilosti i koordinacije nije u potpunosti jasna jer rezultati različitih studija izazivaju polemiku. Moguće je da su uočene razlike u rezultatima istraživanja posljedica razlika u metodološkom pristupu, jer se primjenjuju različiti testovi za procjenu koordinacije i rezultata, a koji nisu dovoljno diskriminatorni (D’Hondt i sur., 2009). Osim toga, koordinacija je multidimenzionalni prostor, koji, zahvaljujući različitim procesima u organizmu (neuropsihološkim, anatomskim, psihološkim, funkcionalnim i biokemijskim), omogućava brojne motoričke funkcije. Zbog svoje latentne strukture koordinacija se ne može izravno mjeriti, ali se procjenjuje s pomoću desetaka različitih standardiziranih motoričkih testova. Zbog kompleksnosti problema i nedovoljno razvijene znanstvene metodologije ne postoji jedinstven stav o tome postoji li jedinstvena koordinacija tijela ili ona može biti i segmentarna, što bi u tom slučaju uvjetovalo postojanje koordinacije gornjih ili donjih ekstremiteta. Osim toga, nije potpuno jasno kombinira li koordinacija ravnotežu i preciznost ili su to dvije nezavisne motoričke sposobnosti. Zbog tih nerazjašnjenih pitanja do sada su standardizirani desetci različitih testova i mjernih instrumenata, što znatno komplicira procjenu te motoričke sposobnosti.

Analiza prethodnih studija ostavlja dojam da pretili ljudi zaostaju u domeni koordinacije u usporedbi s normalno uhranjenim ljudima (Pelemiš, 2016). Autori smatraju da je razlog za takve rezultate taj što pretili ljudi imaju problema u integraciji i obradi senzornih informacija, a čini se da je to posljedica oštećenja rada perceptivnih geštalt motoričkih funkcija (Gentier, D’Hondt, Shultz, Deforche, Augustijn, Hoorne i Lenoir, 2013). Ono što se čini zajedničkim svim studijama, jest stav da, ako se izvode 
pokreti fine motoričke preciznosti, koordinacija ruke i pokreti u kojima je potrebna vještina kontroliranja predmeta, poput pomicanja kovanica, onda ne postoje bitne razlike (Southall, Okely i Steele, 2004). Međutim, ako se procjenjuje koordinacija koja zahtijeva rad većih dijelova tijela ili pokret cijeloga tijela, tada pretili ljudi imaju slabije rezultate (D' Hondt i sur., 2013).

U testovima koji su se u ovoj studiji koristili za procjenu koordinacije (20 koraka $s$ provlačenjem kroz štapove i bacanje lopte), nisu uočene statistički značajne razlike među skupinama, iako je skupina pretilih ispitanika postigla najniži prosječni rezultat. Razlozi zbog kojega nisu uočene značajnije razlike u koordinaciji u korist skupine normalno uhranjene djece vjerojatno se mogu objasniti sadržajem motoričkih zadataka koji su se koristili u testiranju. Na oba testa bilo je potrebno koristiti se određenim predmetima (loptom, štapom) na točno određen način. U drugim studijama u kojima je procjena koordinacije trebala biti odrađena tako što su se ispitanici morali koristiti određenim predmetima, npr. kovanicama, nisu pronađene bitne razlike između rezultata skupine normalno uhranjene djece i skupine pretile djece (Okely, Booth, i Chey, 2004). Izbor testova za čiju bi provedbu bilo potrebno raditi pokrete cijelim tijelom na većim udaljenostima, poput poligona unatraške, agilnosti s pomoću štapa i poligona sa skakanjem i provlačenjem, mogao bi dati različite rezultate.

\section{Veza između indeksa tjelesne mase i rezultata na testovima za procjenu jačine i snage}

Skupina pretilih dječaka ostvarila je statistički slabije rezultate na sljedećim testovima: skok udalj, istezanje trupa i izdržaj u visu zgibom. To su testovi za procjenu eksplozivne snage donjih ekstremiteta, repetitivne snage leđnih mišića i statičke snage savijanja mišića u laktu. Kako smo vidjeli, niski rezultati ostvareni su u testovima trčanja na $20 \mathrm{~m}$ i trčanja na $30 \mathrm{~m}$ koji, osim brzine, testiraju i eksplozivnost mišića donjih ekstremiteta. Slične su rezultate dobili i Castetbon i Anreyeva (2012), koji su uočili da su rezultati pretilih predškolaca na testovima skok udalj $(4,3 \mathrm{~cm}$ u prosjeku) bili oko $20 \%$ slabiji od rezultata skupine normalno uhranjene djece. U istraživanju koje su proveli Graf, Koch, Kretschmann-Kandel, Falkowski, Christ, Coburger i Predel (2004) uspoređivani su motorički koeficijenti pretile i normalno uhranjene djece. Motorički koeficijent dobiven je s pomoću nekih rezultata ostvarenih na tri testa (poligon unatraške, preskakanje prepreka na jednoj nozi i zakret u stranu). Autori smatraju da su lokomotorne kompetencije te vrste izravno povezane s prekomjernom tjelesnom težinom i poremećajem u funkcijama skeletnih mišića u pretile djece. Deforche, De Bourdeaudhuij, D’hondt i Cardon (2009) dobili su slične rezultate s pomoću Eurofit baterije testova kojom su se procjenjivale motoričke sposobnosti pretile i nepretile djece u dobi između 12 i 18 godina.

$\mathrm{Na}$ temelju rezultata dobivenih tijekom ovoga istraživanja smatramo da su dobiveni rezultati takvi zbog neodgovarajuće standardizacije testova koji se koriste u istraživanjima, što je u skladu s istraživanjem koje su proveli Šekeljić, Stamatović, Marković i Marković (2013). Zbog načina na koji se ti motorički zadatci izvode i 
načina na koji se brzina, agilnost, jačina i mišićna snaga procjenjuju, može se reći da su ti testovi (osim dinamometrije ruke) standardni (provode se na isti, određeni način), ali nisu standardizirani (opterećenje nije isto za ispitanike različite tjelesne mase). Kako bi test bio standardiziran, potrebno je da vanjski (mehanički) učinak bude isti za sve ispitanike, što nije slučaj kod navedenih testova. Vanjski učinak, prema osnovnom zakonu mehanike, ovisi o tjelesnoj masi. Zbog toga je odrađeni mehanički rad ispitanika drugačije tjelesne mase različit. Prema drugom Newtonovu zakonu sila je jednaka umnošku mase i ubrzanja $(\mathrm{F}=\mathrm{m} \times \mathrm{a})$. $\mathrm{U}$ međunarodnom sustavu mjernih jedinica newton je mjerna jedinica za silu, a definira se kao količina sile koja tijelu mase od 1 kilograma daje ubrzanje od 1 metra po sekundi za sekundu $\left(1 \mathrm{~N}=\mathrm{kgm} / \mathrm{s}^{2}\right)$. Međutim, newton je također i jedinica za težinu. Zemlja silom gravitacije privlači sva tijela prema svojemu centru. Zato sva tijela pritišću podlogu na koju se oslanjaju. Ukupan pritisak tijela na horizontalnu podlogu na kojoj tijelo stoji ili trakcija kojom gravitacija djeluje na tijelo dok visi zove se tjelesna masa. Na Zemljinoj površini učinak sile gravitacije na tijelo je konstantan - $\mathrm{g}=9,81 \mathrm{~m} / \mathrm{s}^{2}$, a ta vrijednost se zaokružuje na $10 \mathrm{~m} / \mathrm{s}^{2}$. Tjelesna masa $(\mathrm{Q})$ je proporcionalna tjelesnoj težini tijela i sili gravitacije $(\mathrm{Q}=\mathrm{m} \times \mathrm{g})$ pa zato tijelo od $1 \mathrm{~kg}$ teži oko $10 \mathrm{~N}$. Tijekom slobodnoga pada težina tijela dobiva ubrzanje pod utjecajem sile gravitacije. Zbog toga, ako vrijednost ubrzanja gravitacije „g“ stavimo u jedinicu sile $(\mathrm{F}=\mathrm{m} \times \mathrm{a})$ umjesto ubrzanja „a“, vrijednost sile F zove se težina. Tako je tjelesna masa $(\mathrm{Q})$ jednaka umnošku mase $(\mathrm{m})$ i Zemljine sile gravitacije (g). Zbog toga su svi testovi standardni (zato što je protokol izvođenja testova isti), ali nisu standardizirani, jer sila koju osobe različite tjelesne težine primjenjuju na testovima nije jednaka. U prilog tome idu rezultati koji pokazuju da skupina pretilih ispitanika nije imala slabiji rezultat u testu dinamometrija ruke. $\mathrm{Na}$ tom testu bilo je potrebno pritisnuti dinamometar što je jače moguće, a pokazana snaga nije ovisila o tjelesnoj masi ili sili gravitacije.

Istraživanje koje su proveli Markovic i Jaric (2004) pokazalo je da je tjelesna masa važna u testiranju fizičke izvedbe i da se određeni testovi neadekvatno primjenjuju. Istraživanje potvrđuje (Jaric, 2003) klasifikaciju fizičke izvedbe na temelju tjelesne mase tijekom testiranja određenih motoričkih zadataka. Autori, zapravo, navode da je dok su testirali naprezanje vanjske sile (podizanje vlastitoga tijela, guranje ili provlačenje) u testovima brzih pokreta (skakanje i sprint), u obzir bilo neophodno uzeti ulogu alometrijskog odnosa između testiranih vježbi i indeksa tjelesne mase. Standardizacija testova provela bi se s pomoću primjene alometrijskog odnosa koji bi se izračunao formulom $\mathrm{Pn}=\mathrm{P} / \mathrm{Sb}$, gdje je $\mathrm{P}$ testirana izvedba, a $\mathrm{Sb}$ označava indeks tjelesne mase.

\section{Zaključak}

Uzimajući u obzir opseg problema i posljedice koje pretilost može imati, strateški cilj svake zemlje trebao bi biti promicanje umjerene tjelesne aktivnosti i razvoj zdravih životnih navika koje bi doprinijele prevenciji pretilosti i pravodobno utjecale na 
razvoj motoričkih sposobnosti. Ako intervencija ne bude odgovarajuća i pravodobna, problem će se dalje razvijati na već viđen način. Smanjena tjelesna aktivnost pogoršava problem pretilosti te povećava rizik od mnogih bolesti koje su posljedica smanjene tjelesne aktivnosti i pretilosti. Zbog toga bi se, pogotovo u vrtićima i školama, pažnja trebala usmjeriti na interdisciplinarne aktivnosti kako bi se postigli dugotrajni učinci u promjeni nezdravih životnih navika. Intervencije bi se temeljile na poboljšanju stvarnih i percipiranih fizičkih kompetencija djece s prekomjernom tjelesnom težinom, putem različitih modela tjelesnih aktivnosti, a s ciljem učenja i usvajanja osnovnih motoričkih vještina i poboljšanja motoričkih sposobnosti.

U budućnosti bi u cijeloj Srbiji trebalo provesti istraživanja na reprezentativnom uzorku. To istraživanje bilo bi longitudinalno, s pažljivo odabranim motoričkim testovima koji ne bi davali prednost normalno uhranjenim ispitanicima, kao što je slučaj kod većine testova za procjenu jačine. Osim toga, uz studije o praćenju motoričke dimenzije ispitanika i njihova posturalnog statusa, potrebno je odrediti i anatomske i biomehaničke uzroke nedovoljne motoričke razvijenosti. Detaljan uvid u vezu između indeksa tjelesne mase, motoričkih sposobnosti, držanja i drugih komplementarnih čimbenika pokazao bi prave razloge nedovoljno razvijene motoričke sposobnosti, rasvijetlio bi metode koje će se koristiti kao sredstvo prevencije i pomogao u uklanjanju loših posljedica pretilosti. 